\title{
What is the Role of Women When Faced with Personal Conflicts at Work?
}

\author{
Mochamad Soelton* \\ Management Department, Faculty of Economics and Business, Universitas Mercu Buana, Indonesia \\ Noermijati Noermijati \\ Management Department, Faculty of Economics and Business, Universitas Brawijaya, Indonesia \\ Inge Hutagalung \\ Communication Department, Faculty of Communication Studies, Universitas Mercu Buana, Indonesia \\ Nicko Gana Saputra \\ Management Department, Faculty of Economics and Business, Politeknik Sahid, Indonesia \\ Suprapto \\ Management Department, Faculty of Economics and Business, Universitas Mercu Buana, Indonesia \\ Sonia Tiffany \\ Management Department, Faculty of Economics and Business, Universitas Mercu Buana, Indonesia
}

\begin{abstract}
This study aims to examine and analyze the influence of family-work conflict, work stress, and ethical leadership on the desire to leave employees. The research method used in this research is descriptive method. The object of this study is female employees at Life Insurance Company Jakarta - Indonesia with a sample of 95 respondents. The approach used in this research is Structural Equation Model (SEM) with Smart-PLS analysis tool 3.2.8. The results showed that family-work conflict and Job stress has a positive and significant effect on turnover intentions, and ethical leadership has a negative effect on turnover intentions.
\end{abstract}

Keywords: Family-work conflict, work stress, ethical leadership, turnover intention employees.

DOI: $10.7176 / \mathrm{EJBM} / 12-14-01$

Publication date:May $31^{\text {st }} 2020$

\section{INTRODUCTION}

Resource is a potential value contained in a specific material or element in life like nature resources, financial resources, technology and science resources, and human resources (Irviani and Verina, 2015). Human resources are everything that is an asset of the company to achieve its goals. Human resources are a central sector and are important in order to achieve the objectives in a company, because with the ability of the skills of the workers and the quality of human resources, it can run the company properly and correctly. Technology capability is also an important supporting element in running the company, because with the completeness and advance technology, it will facilitate the running of a company. Human resource management is the science, art, processes and practices in the activities of the utilization of human resources in terms of procurement, development, compensation, integration, maintenance and release of human resources in order to achieve organizational goals.

Management of human resources is one of the most important factors that cannot even be separated from an organization, both institutions and companies. The success of a company is not far from the interference of leaders and workers who every day are trying to develop new ideas to optimize their work so that the performance is greatly improve of what is produced. According to Ramli and Soelton (2018), the heavy work pressure makes workers feel stressed. The high turnover intention in a company is a major problem faced by all companies that have an impact on activity and productivity (Soelton and Atnani, 2018).

The company will feel burdened knowing that its employees wants to leave the company, especially if those employees are loyal to the company and are have a good performance. It will be a big loss if the employee wants to leave the company. The main thing that will become a problem in the company is the expenses to conduct the process of employee recruitment up to various training provided to employees (Jumadi et al, 2018). 
Table 1 Employee resignation data of Life Insurance Company

\begin{tabular}{|c|c|c|c|c|c|c|c|c|}
\hline \multirow{2}{*}{ KET } & \multicolumn{2}{|c|}{2015} & \multicolumn{2}{c|}{2016} & \multicolumn{2}{c|}{2017} & \multicolumn{2}{c|}{2018} \\
\cline { 2 - 9 } & Men & Woman & Men & Woman & Men & Woman & Men & Woman \\
\hline TOTAL EMPLOYED & \multicolumn{2}{|c|}{120} & \multicolumn{2}{|c|}{150} & \multicolumn{2}{|c|}{170} & \multicolumn{2}{|c|}{200} \\
\hline OUT & 27 & 33 & 21 & 25 & 23 & 36 & 50 & 80 \\
\hline IN & 24 & 21 & 10 & 5 & 20 & 19 & 41 & 48 \\
\hline \% OUT & $23 \%$ & $28 \%$ & $14 \%$ & $17 \%$ & $14 \%$ & $21 \%$ & $25 \%$ & $40 \%$ \\
\hline
\end{tabular}

\section{Source: Data Human Resource Department, (2019)}

The resignation data was taken for the last 4 years, according to the table 1 above, the number showing a bad result, instability, up and down of resigned employee every month, especially with female employee that causing unfinished tasks and problem for the company. Turnover needs to be a concern because high turnover can interfere with company activities and productivity Soelton and Atnani, (2018, Jumadi Et al, (2018), Hafid and Prasetio (2017), Wahyuni et al (2014).

Turnover Intention has a negative impact on the organization because it creates labour instability, decreased employee productivity, a non-conducive work atmosphere and also human resource costs inflation. This was also justified by the human resource manager who was interviewed by the author. According to Nurhayati (2017), Soelton et al (2018), Adi dan Ratnasari, (2015), Amelia (2019) based on interviews that mostly female employee that resign was still young or just had a first child, where anxiety occurs every day for leaving the baby to work and not wanting to leave the baby with others. Not only that the resign of employees is also based on the desire to get a better job again and seeking new experience. So that it often absent from work to leave the obligation in the company. Turnover was also occurred in PT. Thamrin Brothers Palembang, although with a well-known, good corporate image and always creating interesting programs that can support the needs of their employees, it is still experienced by the company (Amri and Riyanto, 2017). Turnover needs attention because high turnover can disrupt company activities and productivity (Wahyuni et al 2014).

Problems that occur between work and family that make workers feel uncomfortable in the office, some of them split their mind between work and family. Work-family conflict arises when someone facing a problem in their job or family (Latifah and Rohman, in Yani et al 2016). This work stress can cause unstable emotions, feeling uneasy, like to be alone, difficulty sleeping, excessive smoking, unable to relax, anxiety, tension, nervousness, increased blood pressure and experiencing indigestion (Amri and Riyanto, 2017). Work stress influences turnover intention, the results show that the higher the stress felt by employees, the higher the employee turnover intention of Holiday Inn Express Bali Raya Kuta Hotel (Yuda, Ardana 2017). The higher the work stress, the employee turnover intention at Asana Agung Putra Bali Hotel is increasing and vice versa (Septriani et al., 2016).

The bond between ethical leaders and employees is stronger which creates a pleasant environment in this workplace. Therefore it leads to higher commitment and reduces turnover intentions (Mulki et al, in Elci et al 2012). Deconinck (2014) that ethical leadership directly influences employee turnover intention. Demitras and Akdogan (2014) the results show that ethical leadership has direct and indirect effects on the affective commitment and employee turnover intentions.

\section{LITERATURE REVIEW}

\section{Human Resource Management}

According to Hasibuan (2014), HRM is the science and art of regulating the relationships and roles of the workforce to be effective and efficient in helping the realization of company, employee, and community goals. HRM is defined as the utilization of human resources in the organization, which is carried out through the functions of human resource planning, recruitment and selection, human resource development, planning and career development, compensation and welfare, work safety and health, and industrial relations (Marwansyah , 2014). Meanwhile, according to Handoko (2010), human resource management is the withdrawal, selection, development, maintenance, and use of human resources to achieve both individual and organizational goals.

\section{Turnover Intention}

According to Malna et al (in Yani et al 2012), turnover intention is the desire to move or leave a company and has not yet reached the realization stage to actually move to another workplace. Turnover was also experienced by PT. Thamrin Brothers Palembang, although with a big name and a good corporate image and always creating interesting programs that can support the needs of their employees, it is still experienced by the company (Amri and Riyanto, 2017).

According to Mobley (2011), the dimensions and indicators of turnover intention are as follows:

External Factors - Environmental aspects, Individual aspects.

- Internal factors - Organizational Culture, Leadership style, Compensation, Job Satisfaction, Career. 


\section{Work-family conflict}

According to Robbins and Judge (2015) conflict is a process that begins when one party views the other party as having a negative influence or will negatively affect something that the first party cares about. What is meant by family work conflict in this study is as a form of interrole conflict, the roles demanded in work and family will influence each other (Soeharto, 2010). Meanwhile, according to Guitian (in Cristine et al 2010), it explains that family work conflict is correlated with absenteeism, decreased productivity, work dissatisfaction, decreased organizational commitment, lack of life satisfaction, anxiety, fatigue, psychological distress, depression, physical illness, alkolhol use, or tension in marriage, besides that family work conflicts can also reduce performance. Greenhaus et al (in Adityawira et al 2017), said that family work conflicts are more felt by women than men, because women have a greater responsibility to take care of household activities and care for children than men. In general, according to Yani et al (2016), work and family conflicts have 3 dimensions and indicators namely:

- Time-based conflict - Work time demands, Taking care of household, Family and personal responsibilities.

- $\quad$ Strain-based conflict - Work pressure, Stress.

- Behavior-based conflict - Difficulties in meeting needs, Change the activity time, and relax with family due to obligations towards office work.

\section{Job Stress}

According to Moorhead and Griffin (2013), the definition of stress as a person's response to stimulate that take excessive psychological and physical demands on that person. Job stress is the response of people when the demands and work pressures are not in balance with their knowledge and ability to overcome them (Ekawarna, 2018). This work stress can cause unstable emotions, feeling uneasy, introversion, sleeping difficulty, excessive smoking, unable to relax, anxiety, tension, nervousness, increased blood pressure and experiencing indigestion (Amri and Riyanto, 2017). Meanwhile, according to Widiawati et al (2017), work stress is a feeling of pressure or feeling depressed experienced by employees at work. Job stress is characterized by symptoms including unstable emotions, feeling uneasy, introversion, insomnia, unable to relax, anxiety, tension and nervousness.

Indicators and dimensions of work stress according to Cooper (cited by Veithzal \& Ella Jauvani Sagala 2010), namely:

Conditions of work - Workload in internal factors, Workload in external factors, work schedule.

Role - Unclear role.

Interpersonal factors - Collaboration between friends, Relationship with leadership.

- Career development - Promotion to a position lower than his ability, Promotion to a position higher than his ability, Job security.

- Organizational structure - The organizational structure helps employees understand the work environment, Oversight is clear and complies with organizational standards, Involvement in making decisions.

\section{Ethical Leadership}

According to Brown (in Ahmad 2005), stated that demonstration of normative appropriate behavior through personal actions and interpersonal relationships, and the promotion of such behavior to followers through two-way communication, reinforcement, and decision making. That ethical leadership influences job satisfaction, which then influences the intention to quit, which then impacts on job search behavior (Palanski and Avey 2014). In addition, ethical leadership is believed to direct and guide members of the organization towards goals and objectives, which benefit the organization, its members, other stakeholders, and society (Kanungo, 2001).

According to Brown et al (in Prasetiwi, 2019) categorizing ethical leadership dimensions, namely communication, caring, ethical behavior models, treating employees fairly, trusting, and listening to employees. Brown et al (2005) divide the two dimensions of ethical leadership, namely:

The dimension of moral people - Integrity, Caring for others, Justice, Trust.

- The dimension of moral manager - Communicate, Giving awards, Sanctions for violators, and Put more emphasis on ethical standards.

\section{CONCEPTUAL FRAMEWORK AND HYPOTHESIS DEVELOPMENT}

Conceptual Framework

The conceptual framework in this study aims to obtain the direction of research that shows that there is a relationship between Work-Family Conflict, Job Stress Level, Ethical Leadership on Turnover Intention, then the conceptual framework can be taken with the line of thought drawn in the structure diagram as shown below this: 


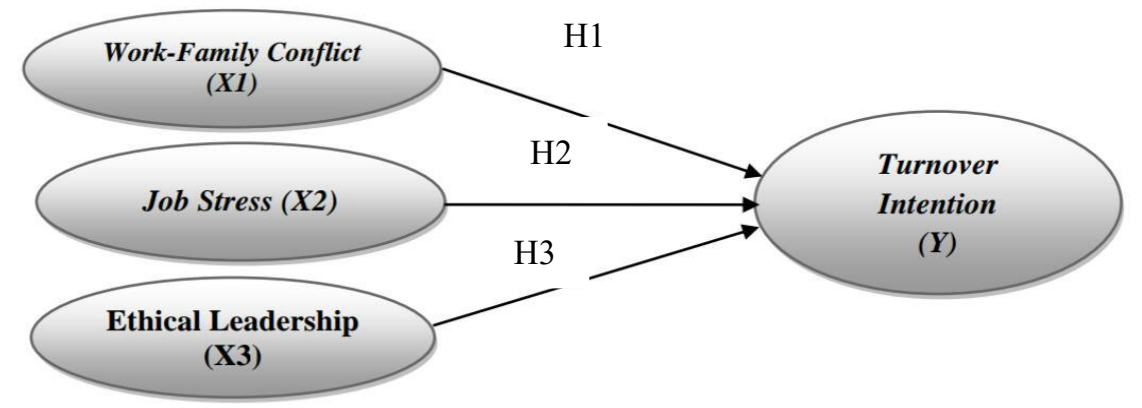

Information:

The independent variable, whose value is not directly related to other values, the variable is given the symbol (X), including:

$\mathrm{X} 1$ : Work-Family Conflict

X2: Job Stress

X3: Ethical Leadership

Variables are not free, variables whose values depend on other variables, variables are given the symbol (Y):

Y1: Turnover Intention effect on employee turnover intentions.

\section{METHODOLOGY}

\section{Scale of Measurement}

In this study, the measurement method uses a Likert scale which is used to measure the attitudes, opinions, and perceptions of a person or group of people about social phenomena. In research, this social phenomenon has been specifically determined by the researcher, hereinafter referred to as the research variable (Sugiyono (2013).

\section{Population and Research Samples}

According to Sugiyono (2013), population is a generalization area consisting of objects or subjects that have certain qualities and characteristics that are determined by research to be studied and then conclusions drawn. In this study the authors took the place of population research in the Life Insurance Company West Jakarta with 95 married female employees.

The sample is part of a particular population of interest. According to Sugiyono (2013), the sample is part of the number of characteristics possessed by the population. Determination of the sample used in this study uses the type of Saturated Sample method. Saturated sample is a technique for determining the sample if all members of the population are used as samples, this is often done if the population is relatively small (Sugiono, 2013). The sample was conducted because of the limitations of researchers in conducting research ranging in terms of funding, time, energy, and a very large population. Therefore, the sample taken must be truly representative. In this study used a sample of 95 female employees who were married. By giving questionnaires to female permanent employees who are married at Life Insurance Company.

\section{Data colletion method}

The data collection method used in this study is the method of collecting field research and library research. Field research was conducted to determine the conditions that occur in the field more clearly and compare with the theories that have been obtained.

\section{Evaluate Measurement (outer) Model}

\section{a. Convergent Validity Test Results}

Convergent Validity testing of the measurement model with reflexive indicators is assessed based on the correlation between item scores and calculated construct scores. Individual indicators are considered valid if they have a correlation value above 0.70 . But in scale development research, loading factors 0.50 to 0.60 are still acceptable. By looking at the output of the correlation output between the indicator and its construct as shown in the table and structural picture below:

Based on Table 2 and Picture 1 above, it appears that the indicators WFC5, JS1, JS2, JS3, JS4, JS11, JS12, TI1, and TI3 have a loading factor value of less than 0.50 . Therefore, the indicator will be removed from the model. Following are the outputs from the omission of indicators and recalculation: 
Tabel 3

Convergent Validity test results (modified)

\begin{tabular}{|c|c|c|c|}
\hline Variable & Indicator & Outer Loading & Information \\
\hline \multirow{6}{*}{ Work Family Conflict } & WFC1 & 0.75 & Valid \\
\hline & WFC2 & 0.88 & Valid \\
\hline & WFC3 & 0.837 & Valid \\
\hline & WFC4 & 0.754 & Valid \\
\hline & WFC6 & 0.882 & Valid \\
\hline & WFC7 & 0.799 & Valid \\
\hline \multirow{6}{*}{ Job Stress } & JS5 & 0.584 & Valid \\
\hline & JS6 & 0.692 & Valid \\
\hline & JS7 & 0.729 & Valid \\
\hline & JS8 & 0.782 & Valid \\
\hline & JS9 & 0.76 & Valid \\
\hline & JS10 & 0.593 & Valid \\
\hline \multirow{5}{*}{ Ethical Leadership } & EL1 & 0.598 & Valid \\
\hline & EL2 & 0.859 & Valid \\
\hline & EL3 & 0.796 & Valid \\
\hline & EL4 & 0.653 & Valid \\
\hline & EL5 & 0.859 & Valid \\
\hline \multirow{6}{*}{ Turnover Intention } & TI2 & 0.617 & Valid \\
\hline & TI4 & 0.727 & Valid \\
\hline & TI5 & 0.769 & Valid \\
\hline & TI6 & 0.768 & Valid \\
\hline & TI7 & 0.838 & Valid \\
\hline & TI8 & 0.573 & Valid \\
\hline
\end{tabular}

\section{Source: Output PLS}

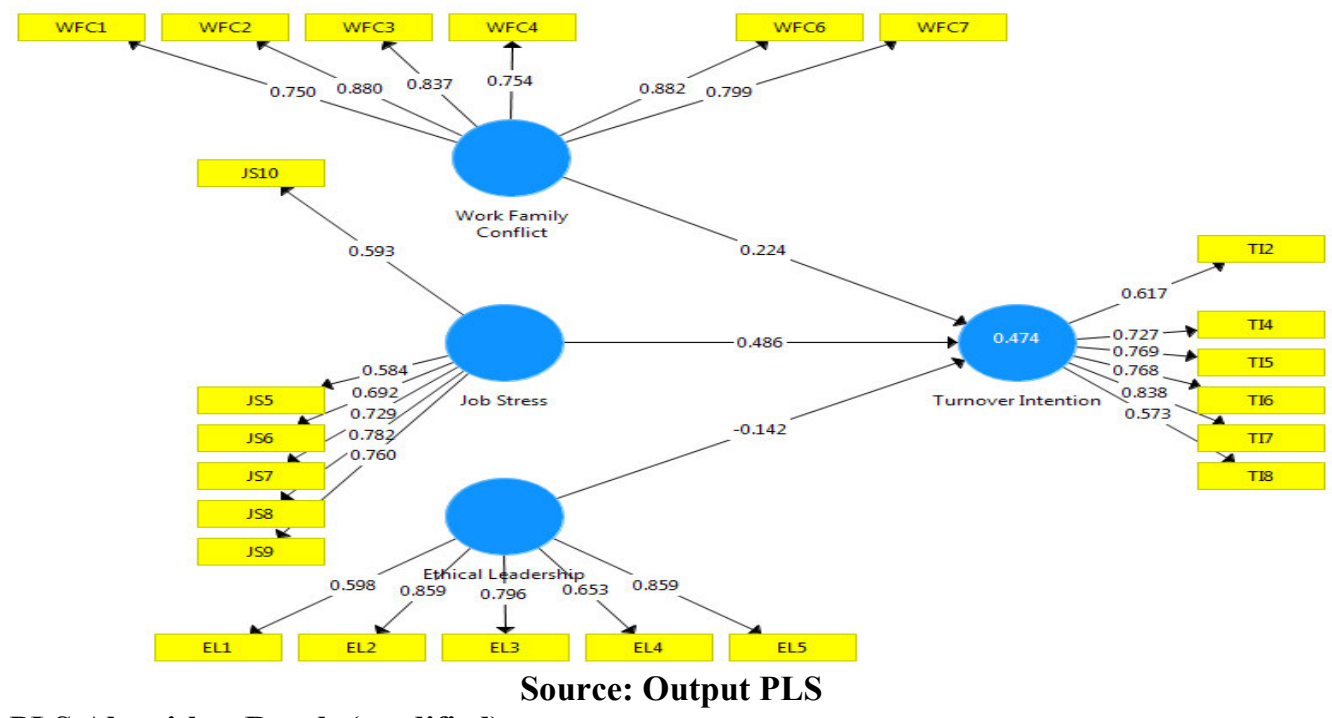

b. PLS Algorithm Result (modified)

The results of the modification of the convergent validity test in Picture 2 and Table 4, can be seen that all indicators meet the convergent validity because it has a loading factor value above 0.50 .

\section{c. Discriminant Validity Test Results}

Discriminant validity testing is a reflective indicator that can be seen in the cross loading between the indicator and its construct. An indicator can be declared valid if it has the highest loading factor to the intended construct compared to loading factor to other constructs. Thus, latent constructs predict indicators in their blocks better than indicators in other blocks. 
Table 4

Discriminant Validity test result (Cross loadings)

\begin{tabular}{|c|c|c|c|c|}
\hline & Work Family Conflict & Job Stress & Ethical Leadership & Turnover Intention \\
\hline WFC1 & 0.75 & 0.407 & 0.036 & 0.315 \\
\hline WFC2 & 0.88 & 0.436 & -0.158 & 0.451 \\
\hline WFC3 & 0.837 & 0.447 & -0.152 & 0.434 \\
\hline WFC4 & 0.754 & 0.296 & -0.023 & 0.348 \\
\hline WFC6 & 0.882 & 0.502 & -0.109 & 0.471 \\
\hline WFC7 & 0.799 & 0.45 & -0.049 & 0.366 \\
\hline JS5 & 0.231 & 0.584 & -0.293 & 0.4 \\
\hline JS6 & 0.386 & 0.692 & -0.086 & 0.392 \\
\hline JS7 & 0.361 & 0.729 & -0.216 & 0.429 \\
\hline JS8 & 0.504 & 0.782 & -0.264 & 0.607 \\
\hline JS9 & 0.295 & 0.76 & -0.327 & 0.467 \\
\hline JS10 & 0.347 & 0.593 & -0.218 & 0.356 \\
\hline EL1 & 0.081 & -0.145 & 0.598 & -0.119 \\
\hline EL2 & -0.216 & -0.395 & 0.859 & -0.347 \\
\hline EL3 & -0.039 & -0.243 & 0.796 & -0.165 \\
\hline EL4 & 0.008 & -0.083 & 0.653 & -0.162 \\
\hline EL5 & -0.059 & -0.277 & 0.859 & -0.312 \\
\hline TI2 & 0.394 & 0.394 & -0.237 & 0.617 \\
\hline TI4 & 0.393 & 0.494 & -0.158 & 0.727 \\
\hline TI5 & 0.331 & 0.497 & -0.414 & 0.769 \\
\hline TI6 & 0.338 & 0.455 & -0.311 & 0.768 \\
\hline TI7 & 0.309 & 0.558 & -0.155 & 0.838 \\
\hline TI8 & 0.374 & 0.4 & -0.137 & 0.573 \\
\hline & & $-0 u r 69$ & \\
\hline
\end{tabular}

\section{Source: Output PLS}

From Table 4 it can be seen that the correlation of work family conflict constructs with its indicators (WFC1 is 0.750 , WFC2 is 0.880 , WFC3 is 0.837 , WFC4 is 0.754 , WFC6 is 0.882 , and WFC7 is 0.799 ) higher than the correlation of work family conflict indicators with other constructs, then the correlation between job stress with the indicator ( $\mathrm{J} 5$ is $0.584, \mathrm{~J} 6$ is $0.692, \mathrm{~J} 7$ is $0.729, \mathrm{~J} 8$ is $0.782, \mathrm{~J} 9$ is 0.760 , and $\mathrm{J} 10$ is 0.593 ) this proves that the indicator is higher than the correlation of job stress indicators with other constructs, then the correlation construct of ethical leadership with its indicators (EL1 of 0.598, EL2 of 0.859, EL3 of 0.796, EL4 of 0.653, and EL5 of 0.859 ) this means that the indicator is higher than the correlation of ethical leadership indicators with other constructs. In the turnover intention construct construct with its indicators (TI2 at 0.617, TI4 at 0.727, TI5 at 0.769, TI6 at 0.768 , TI7 at 0.838 , and TI8 at 0.573 ) higher than the correlation of turnover intention indicators with other constructs.

Another method to look at discriminant validity is to look at the square root of average variance extracted (AVE) value of each construct with the correlation between constructs and other constructs in the model, so it can be said to have a good discriminant validity value.

Table 5

AVE Test Result

\begin{tabular}{|l|l|}
\hline \multicolumn{1}{|c|}{ Variable } & AVE \\
\hline Ethical Leadership & 0.557 \\
\hline Job Stress & 0.531 \\
\hline Turnover Intention & 0.520 \\
\hline Work Family Conflict & 0.671 \\
\hline
\end{tabular}

Source: Output PLS

Table 6

Discriminant Validity Test Result (Fornell Lacker Criterium)

\begin{tabular}{|l|c|c|c|c|}
\hline & Ethical Leadership & Job Stress & Turnover Intention & Work Family Conflict \\
\hline Ethical Leadership & 0.746 & & & \\
\hline Job Stress & -0.341 & 0.728 & & \\
\hline Turnover Intention & -0.331 & 0.651 & 0.721 & \\
\hline Work Family Conflict & -0.103 & 0.520 & 0.492 & 0.819 \\
\hline
\end{tabular}


From Tables 5 and 6 it can be concluded that the square root of the average variance extracted $(\sqrt{ }(\mathrm{AVE})$ for each construct is greater than the correlation between one construct and the other constructs in the model. AVE value based on the table above, it can be concluded that the construct in the estimated model meets the criteria of discriminant validity.

\section{d. Composite Reliability and Cronbach's Alpha Test Results}

Composite reliability and Cronbach's alpha testing aims to test the reliability of the instrument in a research model. If all latent variables have composite reliability and cronbach's alpha values $\geq 0.7$, it means that the construct has good reliability or the questionnaire used as a tool in this study has been reliable or consistent.

Tabel 7

Composite Reliability and Cronbach's Alpha Test Result

\begin{tabular}{|l|c|c|c|}
\hline \multicolumn{1}{|c|}{ Variable } & Composite Reliability & Cronbach's Alpha & Information \\
\hline Ethical Leadership & 0.858 & 0.797 & Reliable \\
\hline Job Stress & 0.847 & 0.783 & Reliable \\
\hline Turnover Intention & 0.865 & 0.810 & Reliable \\
\hline Work Family Conflict & 0.924 & 0.901 & Reliable \\
\hline
\end{tabular}

Source: Output PLS

\section{RESULT AND DISCUSSION}

The measurement model of analysis above shows the link between manifest variables (indicators) and each of the latent variables. The analysis of the measurement model is to test the validity and reliability of each of the dimensions and the indicators utilized to measure the variables constructed earlier. The analysis of the measurement model describe that the value of discriminant validity is by looking at the value of square root of Average Variance Extracted (AVE) with the suggestion value above 0,5, loading factor $(>0.5)$, and constructed Composite Validity and Reliability (Cronbach's Alpha $>0.70$ ). Therefore, the conclusion of the dimensions and indicators which are classified as reliable earlier are showed below:

\section{R-square test result}

According to R-square value which is a goodness-fit model test.

\section{Table 8}

Goodness of Fit Model (GoF)

\begin{tabular}{c|c} 
Endogen Variable & R-square \\
Turnover Intention & 0.474
\end{tabular}

Predictive relevance value is obtained by the formula:

$Q^{2}=1-(1-R 1)\left(1-R_{p}\right)$

$Q^{2}=1-(1-0.474)$

$Q^{2}=1-(0.526)$

$Q^{2}=0.474$

from the above Goodness of Fit table it pointed out that the value of R2 shows that the criteria are strong, with a large $Q$ value, it can be concluded that the proposed model is supported by empirical research which is quite suitable. Likewise, the AVE values are $>0.5$, indicating that all variables in the model are estimated to meet the discriminant validity criteria. The value of Composite Reliability and Cronbach's Alpha for each variable is $>0.70$ (above 0.70 ) meaning that all variables studied are classified as reliable.

Table 9

Hypothesis test result

\begin{tabular}{|l|c|c|c|c|c|}
\hline & $\begin{array}{c}\text { Ori } \\
\text { Sample }\end{array}$ & $\begin{array}{c}\text { Stand } \\
\text { Deviation }\end{array}$ & T Statistics & P Values & Information \\
\hline $\begin{array}{l}\text { Work family conflict - } \\
\text { Turnover intention }\end{array}$ & 0.224 & 0.112 & 2.012 & 0.045 & Positive - Significant \\
\hline $\begin{array}{l}\text { Job stress - Turnover } \\
\text { intention }\end{array}$ & 0.486 & 0.107 & 4.551 & 0 & Positive - Significant \\
\hline $\begin{array}{l}\text { Ethical leadership - } \\
\text { Turnover intention }\end{array}$ & -0.142 & 0.067 & 2.11 & 0.035 & $\begin{array}{c}\text { Negative - } \\
\text { Significant }\end{array}$ \\
\hline
\end{tabular}

Source: Output PLS, 2019 
Figure : The Testing Result

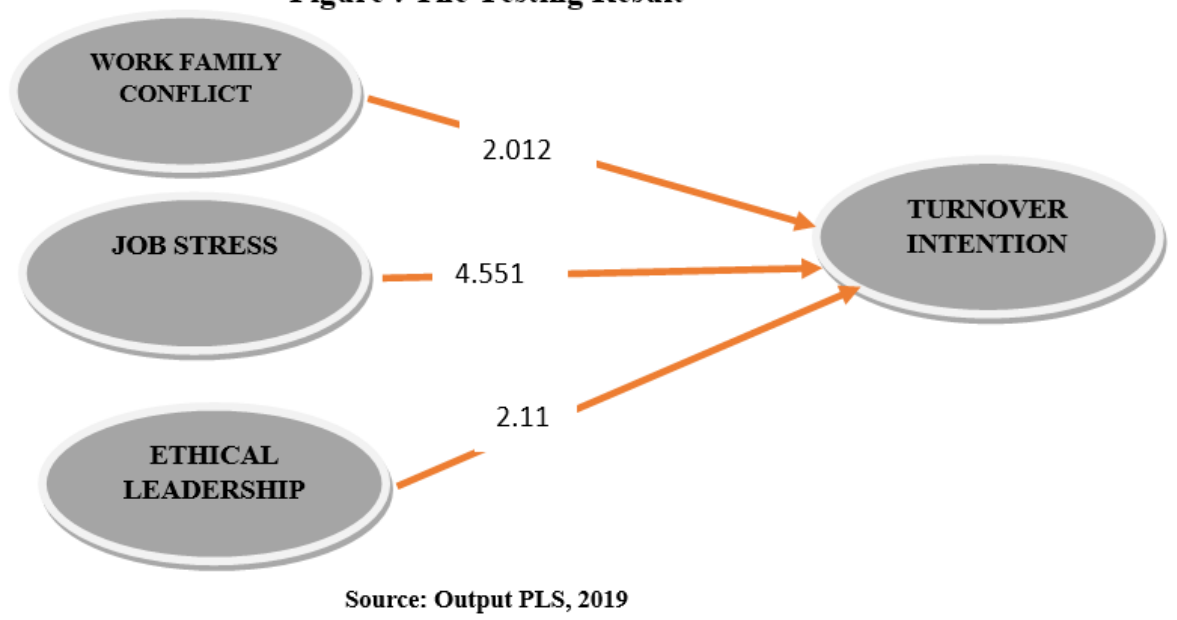

Picture 3

Based on the results of the study above, the research variables show that work stress has the most significant effect on turnover intentions, 4,551 compared to family work conflict in 2.012 and ethical leadership 2.11.

\section{CONCLUSIONS AND RECOMMENDATION}

\section{Conclusion}

This study tries to analyze the variables related to work family conflict, job stress, ethical leadership, and turnover intention. The results of this study were obtained from research on female employees of Life Insurance Company. From the results of calculations in this study, the following conclusions can be drawn:

1. Work family conflict has a significant positive effect on turnover intention in female employees at Life Insurance Company. This means that if a conflict occurs between family and work, it will increase the desire to leave employees in the company.

2. Job stress has a significant positive effect on turnover intention in female employees at Life Insurance Company. This means that if the stress level of employees in working is high, the employee turnover intention will increase.

3. Ethical leadership has a significant negative effect on turnover intention in female employees at Life Insurance Company. This means that if leadership in an ethical company, it will reduce the amount of turnover intention in the company.

\section{Recommendation}

Based on the conclusions above, it can be put forward some suggestions that are taken into consideration for PT. Life Insurance Company as well as for future researchers.

\section{Suggestions for Life Insurance Company}

The company must balance the time given to employees, especially for female employees. For example, by eliminating overtime hours for female employees.

- $\quad$ The company must perform maintenance on the work tools in the company, to avoid damage and hamper employee performance.

- Companies should require the leadership to listen to employee complaints and provide ethical solutions at work.

- Companies must always control both leaders and employees, to avoid leaders who do not care about employees, causing employees to want to leave the company.

\section{REFERENCES}

Adityawira, I., Supriyadi. (2017) Hubungan Konflik Kerja Keluarga Terhadap Motivasi Kerja Dengan Dukungan Sosial Sebagai Variabel Pemoderasi Pada Perawat Wanita Bali Di Rumah Sakit Di Bali, Jurnal Psikologi Udayana, 2017, Vol. 4, No.1, 183-197, ISSN: 23545607

Amri, U., et al, (2017). Pengaruh Kepuasan Kerja, Stres Kerja, Dan Komitmen Organisasi Terhadap Turnover Intention Pada Head Office PT. Thamrin Brothers Palembang, Jurnal Kompetitif Universitas Tridinanti Palembang. Vol.6 No. 1 Ed. Januari - Juli 2017 : 111.

Basri, Y. M., (2012). Hubungan antara Keadilan Prosedural, Job Stress, Komitmen Organisasional dan Keinginan Berpindah Akuntan (Studi pada Tenaga Akuntansi di Provinsi Riau dan Kabupaten Bengkalis). Jurnal 
Akuntansi, Vol. 1, No. 1, Oktober 2012 : 23-37 ISSN 2337-4314.

Brown, M.E., Trevino, L.K., \& Harrison, D.A. (2005). Ethical Leadership: A social learning perspective for construct development and testing Organizational Behavior and Human Decision Processes 97 (2005) 117134.

Christine W., et al (2010), Pengaruh Konflik Pekerjaan Dan Konflik Keluarga Terhadap Kinerja Dengan Konflik Pekerjaan Keluarga Sebagai Intervening Variabel (Studi Pada Dual Career Couple Di Jabodetabek) Jurnal Manajemen Dan Kewirausahaan, Vol.12, No. 2, September 2010: 121-132 122

Deconinck, J.B., (2014) Outcomes of ethical leadership among sales people Dx.Doi.Org/10.016/J.Jbusres.2014.10.011 0148-2963/2014 elsevier.

Demitras, O., \& Akdogan, A.A. (2014) The Effect of Ethical Leadership Behavior on Ethical Climate,Turnover Intention, and Affective Commitment. J Bus Ethics DOI 10.1007/S10551-014-2196-6.

Ekawarna. (2018). Manajemen Konflik Dan Stress, Jakarta: Bumi Aksara

Elci, et al . (2012). The Impact Of Ethical Leadership And Leadership Effectiveness On Employees Turnover Intention : The Mediating Role Of Work Related Stress Procedia-Sosiacl And Behavioral Sciences 58 , 289297.

Ghayyur, M., \& Jamal, W., (2012). Work-Family Conflicts: A Case of Employees Turnover Intention. International Journal of Social Science and Humanity. Vol. 2, No.3.

Ghozali \& Imam. (2014). Structural Equation Modeling, Metode Alternatif Dengan Partial Least Square (Pls). Edisi 4.Semarang :Badan Penerbit Universitas Diponegoro

Guitian. (2009). Conciliating Work And Family: A Catholic Social Teaching Perspec-Tive. Journal Of Business Ethic, 88: 513-524

Handoko (2010). Manajemen Personalia Dan Sumber Daya Manusia, Edisi Kedua, Yogyakarta: BPFE

Hasibun, Malayu S.P. (2014). Managemen Sumber Daya Manusia, Edisi Revisi, Jakarta: Pt. Bumi Aksara

Hughes., Ginnett \& Curphy. (2012). Leadership Memperkaya Pelajaran Dari Pengalaman, Jakarta: Salemba Humanikaa

Irvianti, L. S. D., \& Verina, R. E., (2015). Analisis Pengaruh Stres Kerja, Beban Kerja Dan Lingkungan Kerja Terhadap Turnover Intention Karyawan Pada PT. XL Axiata TBK Jakarta, Binus Business Review, Vol 6 No.1 Mei $2015: 117-126$.

Jumadi, Soelton, M., \& Nugrahati, T., (2018). Bagaimana Beban Kerja Dan Stres Kerja Mempengaruhi Organizational Citizenship Behavior (OCB) Dan Kinerja Karyawan PT. Multitek Indopanca Jakarta, Forum Manajemen Indonesia 10-Palembang, 2018, 501.

Mahdi, et al. (2012), The Relationship Between Job Satisfaction And Turnover Intention, Journal Of Applied Sciences 9 (9): 1518-1526, 2012 Issn 1546-9239

Marwansyah. (2014). Managemen Sumber Daya Manusia, Edisi Kedua, Bandung: Alfabeta

Mas'ud Fuad. (2004), Survai Diagnosis Organisasional Konsep \& Aplikasi : 979-704-246-4, Badan Penerbit Universitas Diponegoro.

M Soelton, P Amaelia, H Prasetyo. 2020. Dealing with Job Insecurity, Work Stress, and Family Conflict of Employees.

4th International Conference on Management, Economics and Business (ICMEB 2019). 2020/2 (167-174). atlantis-press.com

M Soelton, D Amalia, N Noermijati, B Wahyudiono. 2020. Self-Esteem: The Levels of Religiosity in Job Insecurity and Stress in Government Company. 4th International Conference on Management, Economics and Business (ICMEB 2019). 2020/2 (302-310). atlantis-press.com

F Rohman, YB Abadi, M Soelton, N Prasetyo, ET Saratian. 2020. The Effect of Environmentally Friendly Paper Toward Purchasing Intention. 4th International Conference on Management, Economics and Business (ICMEB 2019). 2020/2 (120-126). atlantis-press.com

M Soelton, D Hardianti, S Kuncoro, J Jumadi. 2020. Factors Affecting Burnout in Manufacturing Industries. 4th International Conference on Management, Economics and Business (ICMEB 2019). 2020/2 (46-52). atlantispress.com

M Mugiono, BH Purwoko, M Soelton, R Yuvitasari. 2020. Recognizing How the Job Involvement, Burnout, and Self-Efficacy Work Influences the Work Stress at International Hospitals. 4th International Conference on Management, Economics and Business (ICMEB 2019). 2020/2 (264-270). atlantis-press.com

M Soelton, PA Lestari, H Arief, RL Putra. 2020. The Effect of Role Conflict and Burnout Toward Turnover Intention at Software Industries, Work Stress as Moderating Variables. 4th International Conference on Management, Economics and Business (ICMEB 2019). 2020/2 (185-190). atlantis-press.com

DF Suzabar, M Soelton, M Umar, J Triwulan. 2020. Recognizing How the Time Demands of Work Influences the Turnover Intention in Banking Industry. 4th International Conference on Management, Economics and Business (ICMEB 2019). 2020/2 (40-45). atlantis-press.com

A Nanda, M Soelton, S Luiza, ETP Saratian. 2020. The Effect of Psychological Work Environment and Work 
Loads on Turnover Interest, Work Stress as an Intervening Variable. 4th International Conference on Management, Economics and Business (ICMEB 2019). 2020/2 (225-231). atlantis-press.com

M Nurhayati, A Thoyib, DW Irawanto, 2019. Impersonal Trust and Perceived Organizational Politics on Organizational Commitment. European Research Studies Journal 21 (3), 391-403 | vol: | issue : | 2018

M Nurhayatia, A Thoyib, N Noermijati, 2017. The Role of Political Skills for Organizational Commitment . International Journal of Economic Perspectives 11 (4), 493-498 | vol: | issue : | 2017

M Soelton, R Pratama. 2018. Effect of Recruitment Process, Selection, and Compensation on Frontliner Performance in Bank Industry. Proceeding International Conference on Management Economics and Business of Universitas Mercu Buana (ICMEB 2018). Jilid 2018. ISBN 978-979-99488-3-0

M Soelton, S Ria, F Arifin. 2018. Effect of Organizational Culture, Job Satisfaction, and Engagement on Employee Performance in Government Company. Proceeding International Conference on Management Economics and Business of Universitas Mercu Buana (ICMEB 2018). Jilid 2018. ISBN 978-979-99488-3-0

M Soelton, T Nugrahati, M Sholihin, Riyadhus. 2018. Effect of Work Stress and Workload on Labor Employee Performance in Aqua Danone Indonesia. Proceeding International Conference on Management Economics and Business of Universitas Mercu Buana (ICMEB 2018). Jilid 2018. ISBN 978-979-99488-3-0

M Soelton, L Yuliana. 2018. Effect of Organizational Culture, Organization Commitment, and Work Loyalty on Employee Performance in Manufacture Industry. Proceeding International Conference on Management Economics and Business of Universitas Mercu Buana (ICMEB 2018). Jilid 2018. ISBN 978-979-99488-3-0

M Soelton, D Sabartono. 2018. Effect of Recruitment Process, Selection, and Work Disciline on Employee Performance on Bakmi GM Jakarta. Proceeding International Conference on Management Economics and Business of Universitas Mercu Buana(ICMEB 2018) . Jilid 2018. ISBN 978-979-99488-3-0

M Soelton, A Daryadi. 2018. Effect on Compensation, Work Environment, Education, and Training on Employee Performance or Coffee Bean Outlets in Jakarta. Proceeding International Conference on Management Economics and Business of Universitas Mercu Buana (ICMEB 2018). Jilid 2018. ISBN 978-979-99488-3-0

Mobley, W. H, (2011). Pergantian Karyawan Sebab Akibat Dan Pengendaliannya, Jakarta: PPM dan bisnis 2030.

Moorhead, G \& Griffin. R. W. (2013). Perilaku Organisasi Manajemen Sumber Daya Manusia Dan Organisasi, Edisi 9, Jakarta: Salembah Empat

Noor. Juliansyah. (2011). Metodologi Penelitian, Jakarta: Prenada Media Grup

Palanski., Avey \& Jiraporn. (2014). The Effect Of Ethical Leadership And Abusive Supervision On Job Search Behavior In The Turnover Prose, J Bus Ethics (2014) 121:135-146 Doi 10.1007/S10551-013-1690-6

Paramita \& Subudi. (2017). Pengaruh Konflik Pekerjaan-Keluarga Terhadap Turnover Intention Melalui Mediasi Kepuasan Ke: 6441-6470 ISSN : 2302-8912.

Prasetiwi, T., (2019). Pengaruh Kepemimpinan Etis Terhadap Kinerja Karyawan Dengan Iklim Etis Dan Komitmen Organisasi Sebagai Variabel Mediasi (Studi Pada Karyawan KSPPS BMT Tumang Di Boyolali).

Ramli, Y., \& Soelton, M., (2014), Implementing Innovation Management On Market Attractiveness And Unique Resources To Enhance Business Performance On Organic Fertilizer Industries In Indonesia, Academy F Strategic Management Journal Volume 17, Issue 2, 2018.

Rivai, H. Veithzal dan Sagala, E. Jauvani. (2010). Manajemen Sumber Daya Manusia untuk Perusahaan dari Teori ke Praktik. Jakarta: PT Raja Grafindo

Rivai, H. Veithzal. (2009). Manajemen Sumber Daya Manusia, Edisi Kedua, Jakarta: Rajawali Pers

Robbins, Stephen P. \& Timothy A. Judge. (2013). Organizational Behavior, England: Pearson Education Limited Robbins, Stephen P. \& Timothy A. Judge. (2015). Perilaku Organisasi. Jakarta: Salemba Empat

Roboth. J. Y., (2015). Analisis Work Family Conflict, Stres Kerja Dan Kinerja Wanita Berperan Ganda Pada Yayasan Compassion East Indonesia, Jurnal Riset Bisnis Dan Manajemen Vol.3 ,No.1, 2015:33-46.

Septiari, N. K., \& Ardana, I. K., (2016). Pengaruh Job Insecurity Dan Stres Kerja Terhadap Turnover Intention Karyawan Pada Hotel Asana Agung Putra Bali, E-Jurnal Manajemen Unud, Vol. 5, No. 10, 2016: 6429-6456 ISSN: 2302-8912.

Soeharto, T.N.E.D. (2010). Konflik Pekerjaan-Keluarga Dengan Kepuasan Kerja: Metaanalisis, Jurnal Psikologi, Volume 37, No. 1, Juni 2010: 189 - 194

Soelton, M., Nugrahati, T., Setiawan, M., Rochman, F., \& Pratama, A. (2019). Gender: Stress Levels on Performance in Modern Industry. Archives of Business Research, 7 (2), 72-81, DOI: 10.14738/abr.72.6131.

Soelton, M., Umar, M. (2018). Recognizing How The Time Demands of Work Influences the Turn Over Intention in Banking Industry. European Journal of Business and Management (EJBM), 12 (19)

Soelton, M. (2018). How Culture, Training Standard and Discipline on the Employee Performance Affect Hotel Management. European Research Studies Journal, 21(4), 378-385.

Soelton, M., \& Nugrahati, T. (2018). How Complaining Behaviors Effect on Coping Stress and Anxiety. International Journal of Saudi Journal of Business and Management Studies (SJBMS), 3(6), 623628.

Soelton, M., \& Oktapriatna, N. (2018). How Complaining Behaviors Effect on Performance in Government 
Industries?. International Journal of Saudi Journal of Business and Management Studies (SJBMS), 3(6), 623628.

Soelton, M., \& Rakasidhi, J. (2018). How to Implementation Organization Citizenship Behaviors with performance on Accident insurance service. European Journal of Business and Management (EJBM), 10(15), 10-16.

Soelton, M., Pebriani, P., Umar, M., Triwulan, J., \& Wilantara, J. How transformational leadership, communication, and workload on the employee performance affect shoes industries. South East Asia Journal of Contemporary Business, Economics and Law, Vol. 17, Issue 5(December) ISSN 2289-1560

Soelton, M., Nugrahati, T., Setiawan, M., Rohman, F., \& Pratama, A. (2019). Gender: Stress Levels On Performance In Modern Industry. Archives of Business Research, 7(2).

Soelton, M., \& Atnani, M. (2018). How Work Environment, Work Satisfaction, Work Stress On The Turnover Intention Affect University Management. Jurnal Manajemen dan Bisnis Indonesia, 5(3), 439-448.

Soelton, M., Umar, M. (2018). Recognizing How The Time Demands of Work Influences the Turn Over Intention in Banking Industry. European Journal of Business and Management (EJBM), 12 (19).

Soelton dan Atnani (2018) How Work Environment, Work Satisfaction, Work Stress on theTurnover Intention Affect University Management, Jurnal Manajemen Bisnis Indonesia Vol 5, Nomor 3, Juni 2018. https://doi.org/10.31843/jmbi.v5i3.178.

Sugiono. (2013), Metode Penelitian Bisnis, Bandung: Penerbit Alfabeta.

Sugiono. (2014), Metode Penelitian Bisnis, Bandung: Penerbit Alfabeta.

Sutrisno \& Edy. (2016). Manajemen Sumber Daya Manusia. Jakarta: Prenada media Group.

Sutrisno, Edi. (2010). Manajemen Sumber Daya Manusia Edisi Pertama. Jakarta: Kencana Prenada Media Group.

T, Babalola, Stouten, \& Euwema. (2013). Frequent Change And Turnover Intention: The Moderating Role Of Ethical Leadership Doi 10.1007/S10551-014-2433-Z.

Wahyuni, A. S., et al, (2014). Analisis Faktor-Faktor Yang Mempengaruhi Turnover Intention (Keinginan Berpindah) Karyawan Pada Perusahan Jasa Konstruksi. Jurnal Rekayasa Sipil / Volume 8, No.2 - 2014, ISSN $1978-5658$.

Waspodo, Agung AWS, Nurul Chotimah Handayani, Widya Paramita. 2013. Pengaruh Kepuasan Kerja dan Stres Kerja Terhadap Turnover Intention pada Karyawan PT. Unitex di Bogor. Jurnal Riset Manajemen Sains Indonesia (JRMSI). Vol.4, No.1.

Widiawati, F., Amboningtyas, D., Rakanta, A.M., \& Warso, Moh.M. (2017). Pengaruh Beban Kerja, Stres Kerja Dan Motivasi Kerja Terhadap Turnover Intention Karyawan PT. Geogiven Visi Mandiri Semarang, Journal Of Management Issn:2502-7689, Vol 3, No. 3 (2017).

Wulandari \& Adnyani. (2016). Pengaruh Work Family Conflict Terhadap Turnover Intention Melalui Mediasi Kepuasan Kerja Pada Hotel Grand Inna Kuta E-Jurnal Manajemen Unud, Vol. 5, No. 10 : 6146-6173 ISSN : 2302-8912.

Yani., Sudibya., \& Rahyuda. (2016). Pengaruh Work-Family Conflict Dan Stres Kerja Terhadap Kepuasan Kerja Dan Turnover Intention Karyawan Wanita E-Jurnal Ekonomi Dan Bisnis Universitas Udayana 5.3 : 629-658 ISSN : 2337-3067.

Yuda, I.B.D.P \& Ardana, I.K., (2017). Pengaruh Kepuasan Kerja Dan Stres Kerja Terhadap Turnover Intention Pada Karyawan Hotel Holiday Inn Express. E-Jurnal Manajemen Unud, Vol. 6, No. 10, : 5319-5347.

Yukl, G., (2013). Leadership In Organizations, Eighth Edition, England: Pearson Education Limited

Yunita \& Kismono. (2014) Influence Of Work-Family Conflict And Family-Work Conflict On Employees' Turnover Intentions With Gender, Social Support And Individual Value As Moderating Effects Journal Of Indonesian Economy And Business Volume 29, Number 1, 2014, 17 - 30. 